\title{
The Changes of Activity and Isozyme-pattern of Lactate Dehydrogenase in Human and Rat Uterus
}

\section{Yoshihiro TAKAHASHI, Yuko SANJO, Akio NOMURA, Taizo TAKEMOTO, and Masao MAEYAMA}

Department of Obstetrics and Gynecology, Nara Medical College, Kashihara, Japan.

(Director : Professor Masao Maeyama, M.D.)

The changes in activity of LDH (L-lactate:NAD oxidoreductase, EC 1.1.1.27) as well as $\mathrm{LDH}$ isozyme-pattern were studied with hormone administered and pregnant rat uterus and with pregnant human uterus.

LDH activity was raised 16-24 hours after the administration of $10 \mu \mathrm{g}$ estradiol-17 $\beta$ to the ovariectomized rat. LDH-isozyme-pattern revealed a shift toward LDH V $\left(\mathrm{M}_{4}\right)$. Prolonged administration of estrogen resulted in the increase of distribution of $\mathrm{M}$ subunits in the rat uterus which closely resembled the skeletal muscle type pattern in LDH zymogram. The concomitant administration of progesterone $(10 \mathrm{mg} / \mathrm{rat} / \mathrm{day})$ did not inhibit but rather tended to enhance the increase of $\mathrm{LDH}$ activity induced by estradiol administration. Concomitantly used progesterone, however, considerably inhibit the increase of $\mathrm{M}$ subunits induced by estrogen.

In muscle tissue of the late pregnant human and rat uterus, activity of $\mathrm{LDH}$ was raised and the isozymes changed in the increase percentage of $\mathrm{M}$ subunits, namely $\mathrm{LDH}, \mathrm{V}>\mathrm{IV}>$ III $>$ II $>$ I in myometrium of late pregnant rat, and IV $>$ V $>$ III $>$ II $>$ I in human term pregnant myometrium.

It has been well established that five isozymes of $\mathrm{LDH}$ are the tetramer consisting of two subunits, $\mathrm{M}$ and $\mathrm{H}$, of which amino acid sequence is different from each other and independently controlled by different genes. Proliferative tissue with anaerobic glycolysis contains mainly M-LDH which is not inhibited by high concentration of pyruvate, while in tissues with rather aerobic glycolysis H-LDH sensitive to pyruvate distributes in a much higher proportion.

The fact that the isozyme-pattern of LDH in human and rat uterine muscle resembles that of skeletal muscle, and with the advance of pregnancy the elevation of activity of glycolytic key enzymes (previously reported) indicates a metabolic change of the pregnant uterus into a glycolytic tissue. This may well be explained by the need of rapid energy supply of pregnant uterus at delivery. The distinct response in the isozyme-pattern of estrogen treated from estrogen-progestogen treated uterus suggests the different action of estrogen and progestogen on two genetic loci controlling the synthesis of $\mathrm{M}$ and $\mathrm{H}$ subunits.

(See pp. $24 \sim 27$ ) 


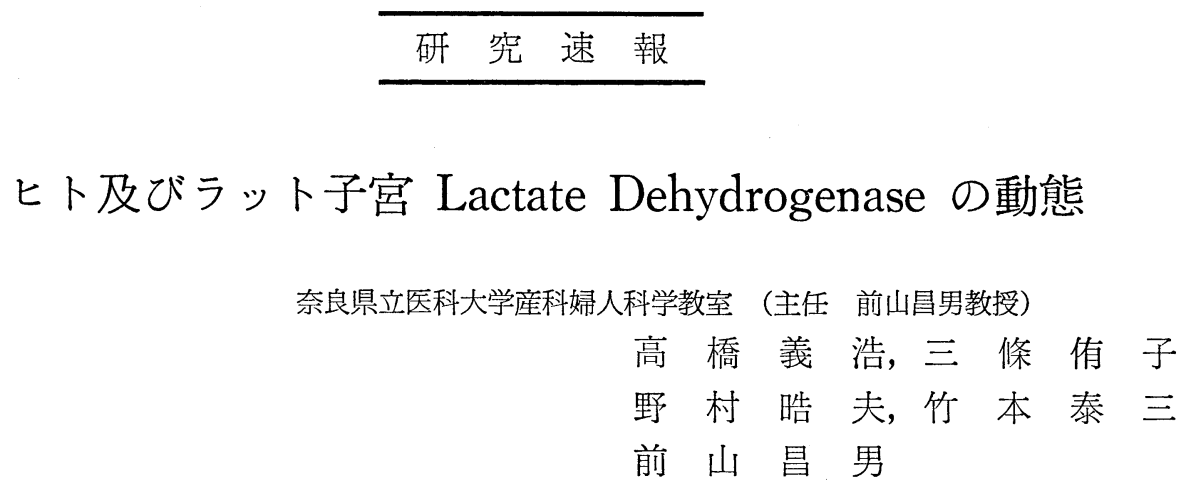

（昭和44年11月14日受付）

分子レベルでその代謝調節機構の明らかな LDH-isozyme の動態を，ヒト及びラット子宮について 検索を行ない， estrogen 投与ラット子宮では，その M-subunit の増加， progestogen 同時投与によ り，その抑制か認められた。 また，妊娠子宮筋 LDH-isozyme はヒト及びラット共にその末期に Msubunit の著增が認められ，解糖能の強い組織となつているととが証明された。

\section{は じめに}

先に, ヒト及びラット子宮の glycolytic key enzymes の動態を妊娠時及びホルモン投与時について追求 を行い，ヒト及びラット子宮筋組織では，弤娠時その活性が上昇し，解糖能の強い組織となるてと，また estrogen, progestogen + estrogen 投与により，ラット子宮 glycolytic key enzymes 活性が増加するてと から，妊娠時のての酵素活性脬導は，内因性 estrogen, progestogen によるものであるてとを明らかにし $た^{132)}$ ．今回は，pyruvate $\longrightarrow$ lactate の反応を触媒し，しかも，その isozyme について分子レベルで明ら かな lactate dehydrogenase (L-lactate : NAD oxidoreductase, EC 1.1.1.27) そついて検討を行なつた.

\section{実験材料並びに方法}

動物：体重 160 200gm の去勢雌ラット（去勢後 3 週間目）を用い，妊娠ラットは臸内に sperm を証明し た日を妊娠第 1 日として, それぞれの妊娠日数のものを用いた。投与ホルモン : estradiol-17 $\beta$ (E) $20 \mu \mathrm{g} / \mathrm{ml}$ 水溶液, progesterone $(\mathrm{P}) 10 \mathrm{mg} / \mathrm{ml}$ ゴマ油溶液, 一部の実験には estradiol dipropionate, 17 $\alpha$-hydroxyprogesterone capronate を用いた. 投与は皮下投与, 量はそれぞれ実験成績で述べる.

酵素液の調整：ホルモン投与例は全子宮を，妊娠産裖例は内膜を除去し筋層のみとして用いた。 ヒト子宮 筋組織は手術時, 一部を biopsy し, 直ちに freeze したものを用いた. 子宮組織に $0.01 \mathrm{M} \mathrm{NaCl}$, あるい は $0.04 \mathrm{M}$ veronal buffer $\mathrm{pH} 8.4$ を加光 10\% homogenate を作成, $10,000 \mathrm{xg}$ 30分遠沈上清を用い, electrophoresis 亿，適当に稀秎したものを LDH 活性の測定に用いた。

LDH-zymogram の作成は Wieme ${ }^{3)}$, Van der Helm ${ }^{4)}$ の寒天電気泳動, nitrotetrazolium 醉素染色法任 よつた.すなわち $0.04 \mathrm{M}$ veronal buffer $\mathrm{pH} 8.4$ で1.2\%の溶融寒天を作成し, それをガラス板上に展開, 放冷, 子宮組織 10\% homogenate 上清の $2 \sim 3 \mu 1$ を添加（試料の活性値に応じて量を加減し，泳動槽に 装着, $6 \mathrm{v} / \mathrm{cm}$ になる様に電流調整し, 定電流方式で90分泠却箱内で通電した。泳動後直ちに lactate, KGN, phenazine methosulfate, NAD, nitrotetrazolium, $0.06 \mathrm{M}$ Tris. buffer $\mathrm{pH} 7.4$ の反応液中で $37^{\circ} \mathrm{C}, 60$ 分 
incubation 後, 酢酸. エターノル液にて固定した.ついでセロファン紙に固定移動させ, Beckman Recording Densitometer にて densitometry を行なつた.

なお， LDH 活性は Kornberg 法 ${ }^{5}$ にて測定した。

\section{実 験 成 績}

\section{1）ホルモン投与ラット子宮 LDH-isoyzme}

去勢ラットに $\mathrm{E} 10 \mu \mathrm{g}$ 投与し， 24 時間後子宮では明らかに LDH-V のしめる比率が増加し，去勢対照子 宮に比し，M-subunit の増加か認められた。 3，5 日間連続投与により，乙の傾向は一層明らかとなつた.

$\mathrm{E} 10 \mu \mathrm{g}$ に P 10mg を同時投与すると，1回投与では明らかではないが 3，5 日間投与後 24 時間の子宮

Table 1. Percentage distribution of activity of LDH-isozymes in uterus of ovariectomized rat following the hormones administration by agar gel electrophoresis

\begin{tabular}{|c|c|c|c|c|c|c|}
\hline \multirow[b]{2}{*}{ Treatment } & & \multicolumn{5}{|c|}{ LDH-isozymes } \\
\hline & & I & II & III & IV & $\mathrm{V}$ \\
\hline Castrated control & & $4.1 \pm 1.7$ & $22.1 \pm 4.0$ & $25.0 \pm 1.8$ & $27.8 \pm 3.7$ & $21.0 \pm 4.0$ \\
\hline \multirow{3}{*}{ Estradiol $10 \mu \mathrm{g} / \mathrm{day}$} & $\times 1$ & $2.5 \pm 0.8$ & $15.5 \pm 1.8$ & $20.0 \pm 2.6$ & $31.0 \pm 1.0$ & $31.0 \pm 4.2$ \\
\hline & $\times 3$ & $0.5 \pm 0.5$ & $8.0 \pm 1.3$ & $17.5 \pm 1.3$ & $32.0 \pm 1.8$ & $42.0 \pm 2.8$ \\
\hline & $\times 5$ & $2.5 \pm 0.9$ & $10.0 \pm 1.0$ & $18.5 \pm 0.8$ & $29.0 \pm 0.6$ & $40.0 \pm 2.1$ \\
\hline \multirow{3}{*}{$\begin{array}{l}\text { Estradiol } 10 \mu \mathrm{g} / \text { day } \\
++ \\
\text { Progesterone } 10 \mathrm{mg} / \text { day }\end{array}$} & $\times 1$ & $2.5 \pm 0.6$ & $15.5 \pm 2.3$ & $22.0 \pm 3.7$ & $33.0 \pm 1.0$ & $27.0 \pm 4.8$ \\
\hline & $\times 3$ & $6.5 \pm 4.1$ & $16.0 \pm 2.9$ & $30.0 \pm 4.9$ & $27.0 \pm 3.8$ & $20.5 \pm 4.7$ \\
\hline & $\times 5$ & $4.0 \pm 1.7$ & $24.5 \pm 3.1$ & $32.0 \pm 2.2$ & $24.5 \pm 5.2$ & $15.0 \pm 3.1$ \\
\hline E.D. $1 \mathrm{mg} /$ week & $\times 3$ & $1.0 \pm 0$ & $8.0 \pm 0.8$ & $15.0 \pm 2.2$ & $27.0 \pm 0.8$ & $49.0 \pm 3.7$ \\
\hline $\begin{array}{l}\text { E.D. } 1 \mathrm{mg} / \text { week } \\
++ \\
\text { OH-P.C. } 12.5 \mathrm{mg} / \text { week }\end{array}$ & $\times 3$ & $3.5 \pm 1.7$ & $21.5 \pm 1.3$ & $26.5 \pm 3.3$ & $24.5 \pm 2.1$ & $24.0 \pm 1.9$ \\
\hline
\end{tabular}

E.D. : Estradiol dipropionate, OH-P.C. : $17 \alpha$-hydroxyprogesterone capronate. Each value is expressed as mean \pm S.D. of 3 experiments and control value is mean \pm S.D. of 9 experiments (1-3 uteri, each).

では明らかにEによる M-subunit の増加の抑制 が認められた。

Estradiol dipropionate $1 \mathrm{mg}$ 毎週投与， 3 回 投与後 1 週目子宮では，LDH-V $\left(\mathrm{M}_{4}\right)$ の著明な 増加が認められた. 17 $\alpha$-hydroxyprogesterone capronate 局時投与し!た場合:は estradiol dipropionate による M-subunit の増加が抑制さ れ，その LDH-isozyme pattern は去勢ラット 子宮の pattern に類似した. (Table 1). その zymogram 灰 Fig. 1 亿示した.

なお， $\mathrm{LDH}$ 活性は $\mathrm{E}$ 投与 $16 〜 24$ 時間で明らか な増加を示し， $\mathrm{P}$ 同時投与によりその活性抑制は 認められなかつた。

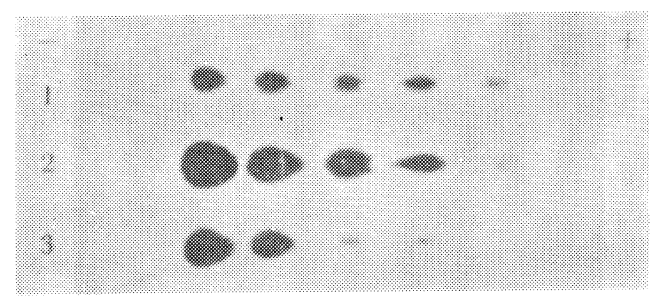

Fig. 1. LDH-zymogram of rat uterus.

1. Control uterus of castrated rat

2. Uterus treated with estradiol dipropionate $1 \mathrm{mg}+17 \alpha$-hydroxyprogesterone capronate $12.5 \mathrm{mg} /$ week $\times 3$

3. Uterus teated with estradiol dipropionate $1 \mathrm{mg} /$ week $\times 3$ 


\section{2）妊娠ラット子宮筋 LDH-isozyme}

妊娠ラット子宮筋の LDH-isozyme pattern をみると妊娠12日子宮筋では，LDH-IV, $>$ III, $>$ V, $>$ II $>$ I の percentage distribution を示したが，妊娠16，21日では，V $>I V>I I I>I I>I の$ pattern を示し，明 らかに M-LDH の増加が認められた。産裖 7 日目子宮筋では LDH-isozyme の分布は妊娠末期と同し pattern を示したが，M-subunit の減少が認められた（Table 2).

LDH 活性は去勢対照子宮 $0.373 \pm 0.018$ (mean \pm S.D.) $\mu$ moles lactate formed $/ \mathrm{min} . / \mathrm{mg}$ protein, 妊娠 中期（10～12日目），末期（18～21日目）子宮筋ではそれぞれ $0.496 \pm 0.053 ， 0.831 \pm 0.068 \mu$ moles lactate formed $/ \mathrm{min} . / \mathrm{mg}$ protein で妊娠末期には明らかに増加を示した。

Table 2. Percentage distribution of activity of LDH-isozymes in uterine muscle tissue of pregnant and postpartal rat

\begin{tabular}{l|r|r|r|r|c}
\hline & \multicolumn{5}{|c}{ LDH-isozymes } \\
\cline { 2 - 6 } Subject & I & II & III & IV & V \\
\hline Pregnancy 12th day & 3.5 & 16.2 & 25.6 & 32.0 & 22.7 \\
Pregnancy 16th day & 2.5 & 7.9 & 10.5 & 24.3 & 54.8 \\
Pregnancy 21st day & 1.5 & 6.3 & 10.6 & 31.9 & 49.7 \\
Postpartum 7th day & 6.0 & 16.6 & 19.0 & 26.7 & 31.7 \\
\hline
\end{tabular}

Each value is average of 2 experiments.

\section{3）ヒト子宮筋 LDH-isozyme}

正常周期を有するヒト子宮筋の LDH-isozyme は LDH-III が最も多く，排卵前期，後期及び閉経婦人 子宮筋で，その pattern に有意の差は認められなかつた。妊娠10力月の子宮筋 isozyme pattern は LDHIV $>V$ > III $>$ II $>$ I を示し，M-subunit の明らかな増加が認められた（Table 3). ヒト子宮筋 LDH 活 性は正常周期例 $0.482 \pm 0.038$ (mean \pm S.D.) $\mu$ moles lactate formed $/ \mathrm{min} . / \mathrm{mg}$ protein ( 7 例), 妊娠 10 力 月例 $0.686 \pm 0.079 \mu \mathrm{moles} / \mathrm{min} . / \mathrm{mg}$ protein (6 例) であつた.

Table 3. Percentage distribution of activity of LDH-isozymes in human uterine muscle tissue

\begin{tabular}{l|c|c|c|c|c|c}
\hline \multirow{2}{*}{$\begin{array}{c}\text { Subject } \\
\text { Number }\end{array}$} & \multicolumn{5}{|c}{ LDH-isozymes } \\
\cline { 3 - 7 } & of Exp. & I & II & III & IV & V \\
\hline Preovulatory & $(6)$ & $4.8 \pm 2.0$ & $20.6 \pm 4.0$ & $40.4 \pm 2.4$ & $28.2 \pm 3.9$ & $6.0 \pm 1.6$ \\
Postovulatory & $(5)$ & $6.4 \pm 2.5$ & $26.2 \pm 3.4$ & $39.6 \pm 5.6$ & $21.8 \pm 4.2$ & $6.0 \pm 1.6$ \\
Menopause & $(5)$ & $4.8 \pm 2.2$ & $25.6 \pm 3.7$ & $42.8 \pm 5.7$ & $21.4 \pm 4.0$ & $5.4 \pm 2.2$ \\
Pregnancy (3M) & $(3)$ & $1.8 \pm 0.9$ & $16.6 \pm 1.3$ & $39.3 \pm 1.7$ & $32.5 \pm 1.8$ & $9.8 \pm 1.3$ \\
Pregnancy (10M) & (6) & $2.3 \pm 1.3$ & $4.5 \pm 2.2$ & $25.3 \pm 3.7$ & $38.6 \pm 2.1$ & $29.3 \pm 4.6$ \\
\hline
\end{tabular}

Each value is mean \pm S.D. .

\section{考察並びに結論}

LDH は lactate——pyruvate の反応を触媒する酵素であるが，すべての動物の LDH は M, H の 2 つ の subunitよりなり，前者は主として骨格筋，後者は心筋にその起源があり，各組織あるいは血清中の LDH はこの二つの type の subunit が tetramer となつてその LDH 分子を構成している. この二つの 
M-, H-LDH はその amino 酸構成を異にし， catalytic な性質および immunological な性質を異にし， 興味あるととには，それぞれ異る gene の支配下にあると考えられている ${ }^{6) \sim 9}$.

また，H-LDH は pyruvate $\rightarrow$ lactate の反応で比較的低濃度の pyruvate で抑制を受け，M-LDH は高 濃度 pyruvate によつても抑制を受けない1011)，すなわち H-type はより aerobic な代謝をする組織に認 められ，M-type はより anaerobic な代謝を行う組織に存在する。

一般に骨格筋は M-LDH のしめる比率が大であるが，急速な収縮運動をする筋と比較的，急速収縮運動 を必要としない筋によつてその M-type LDH 亿多少のあるてとはよく知られた事実である ${ }^{12}$. 一方, 增殖 の盛んな腫煌組織ではその隣接正常組織より一般に M-subunit が高濃度に存し, 高い解糖能を有するとい う事実がある13). かくのでとく LDH についてはその代謝調節機構が分子レベルで明らかとなつている。

Kaplan $~^{14)}$ は幼若家鬼あるいは去勢ラットに estrogen を投与するとその 標的臟器である子宮の LDH の活性の上昇が認められ，しかもその増加は M-type の増加であり DNA-dependent RNA 阻害剂である actinomycin で阻害されるとてろから, estrogen はその標的臟器の gene 飞働き, M-LDH の新合成を誘 導し，その藏器の代謝調節を行なつているととを報告している。

われわれの去勢ラットの estrogen 投与実験でも同様成績をえたが， progestogen 同時投与により，MLDH の estrogen による増加が明らかに抑制される結果を元，その子宮 LDH-isozyme pattern は去勢 子宮と類似したが，LDH 活性の抑制は認められずかえつてその増加か認められたととは LDH の M-, Hsubunit がそれぞれ異る gene regulation を受けていること竞を考えると progestogen 同時投与により何 らかの型で estrogen による gene activation と異る調節を gene に与えたてとが推定出来，また糖代謝 の面よりも estrogen 単独投与と progestogen 同時投与により, 去勢ラット子宮は前者により anaerobic な代謝，後者により aerobic な代謝を営む組織に化学的修飾をうけたととが推定出来る。

ラット弤娠子宮筋 LDH-isozymes pattern はその末期に M-LDH の著増を示し，その pattern は estrogen 投与群と類似していた。 ヒト妊娠子宮筋では10カ月子宮で M-LDH の増加を認めたが LDH-IV が 最高比率をしめ, その成績は Geyer ${ }^{15}$ ) の報告と一致した。 ヒトおよびラット妊娠子宮筋は M-LDH の增加 したてとより解糖能の強い組織に内因性ホルモンによつて化学的に修飾されたてとは明らかである。

\section{文献}

1）高橋義浩, 岸田秀雄, 竹本泰三, 斉藤守重 : 日本内分泌誌, $45: 738$, (1969). 2 2) 高橋義浩, 德井 宏, 岸田秀雄, 斉藤守重 : 日本内分泌誌, $45: 823$, (1969). 3$)$ WIEME, R.J. : Clin. Chim. Acta, $4: 317$, (1959). 4 4) VAN DER HELM, H.J. : Clin. Chim. Acta, $7: 124$, (1962). 5) KORNBERG, A.: Methods in Enzymology, I : 441, Academic Press Inc., N.Y. KAPLAN, N.O. and M.M. CIOTTI : Ann. N.Y. Acad. Sci., 94 : 701, (1961).

7) CAHN, R.D., N.O. KAPLAN, L. LEVINE, and E. ZWILLING : Science, $136: 962$, (1962). MARKERT, C.L. and H. URSPRUNG : Develop. Biol., $5: 363$, (1962). and G. PFLEIDERER : Angewandte Chem., $1: 169$, (1962).

9) WIELAND, T. 10) KAPLAN, N.O. Regulatory effect of enzyme action, Mechanisms of action of steroid hormones, 247, (1961). Pergamon Press, Oxford. 11) KAPLAN, N.O. : Proc. Fifth Intern. Cong. Biochem., III : 97, (1963). Pergamon Press, Oxford. 12) KAPLAN, N.O. and R.D. GHAN : Proc. Natl. Acad. Sci. U.S., 48 : 2123, (1962). Regulation, $2: 203$, (1964). 13) KAPLAN, N.O. and T.L. GOODFRIEND : Advan. in Enzyme 14) GOODFRIEND, T.L. and N.O. KAPLAN : J. Biol. Chem., 239 : 130, (1964). 15) GEYER, H. : Klin. Wschr., $46: 390$, (1968).

(本論文の要旨は第16回日本内分泌学会西部会総会及び第 21 回日本産料婦人科学会総会, 前山昌男教授の 宿題報告の一部として発表した。) 